\title{
On the Development of Ethnic Regions in Northwest of China and the Islamic Finance: Based on the "New Silk Road Economic Belt"
}

\author{
Haiying Ma* \\ School of Economics, Northwest University for Nationalities Lanzhou (730124), P.R.China, \\ Ixmahaiying8888@163.com
}

Keywords: New silk road economic belt; IsImic finance; Ethnic regions; Northwest

\begin{abstract}
The "New Silk Road Economic Belt" strategy has become the focus of global attention. It is not only the symbol of China's rise in the world, but also fully embodies Chinese development from international vision. Along the "silk road economic belt" regions, the most important factor is the common religious beliefs and the close economic and cultural exchanges in the development of Islamic finance. The regional economy and even the global economy is playing an increasingly important role. Based on the characteristics of Islamic finance in northwest China, development trend and the advantage of the development of Islamic finance under the background of the "New Silk Road Economic Belt", the paper appoints that opportunity is mature to Islamic finance for the regional development in northwest China.
\end{abstract}

\section{Introduction}

The "New Silk Road Economic Belt" is to reconstruct international economic relations in China, form a new pattern of opening to the outside of the major strategic measures; Is to promote the western region from the hinterland of reform and opening up to the front, build a new domestic regional economic relations, will create new economic growth point of major engine. Economic belt "silk road" linking Asia and Europe, connection, history is an important cultural promenade, trade channels, China's northwestern region of Xinjiang, Gansu, Shaanxi, Qinghai, Ningxia and other provinces, to the west is adjacent to Russia, east Asia and other countries, known as "silk road economic belt" golden section. The east of the channel is the main distribution area of the world's Muslim population. At present, there are the world's Muslim population about 1.6 billion. Approximation of the cultural and religious roots, making the Islamic economic community in the world economic system has gradually formed, Islamic finance has become an integral part of the world's financial field, supporting the Islamic economic development, its market prospect is quite optimistic. According to Price Waterhouse Coopers (PWC) in five years from 2013 to 2017, the world's Islamic financial assets will be growing at a rate of $17 \%$ a year, total of $2 . \$ 7$ trillion (Jiang 2014). China Islamic finance in recent years is also growing.

The study of Islamic finance and related literature is becoming more and more focused on research the difference between the Islamic finance and modern finance and opportunities and challenges of developing Islamic finance in China. Zhang (2012) pointed out that the essence of Islamic finance business is to emphasize the risk-sharing, profit sharing product leasing revenue or income is designed to be in the form of profit sharing. Li (2009) argues that as a kind of unique financial situation, Islamic finance has its foundation of religious, political and economic basis, and points out that Islamic bank financial products, Islamic bond, Islamic fund, Islamic insurance and other kinds of Islamic financial instruments each has its own characteristics. Jiang (2014) pointed out that China's current financial system open to the public's strength is not enough, mainly in its access to market access, access to business and technology there are many obstacles. The research achievements of Islamic finance in the late stage of China's development, which provides theoretical guidance and practical issues. 


\section{The Islamic Finance Around the World}

Overall, the development of Islamic finance is still in the early, but the momentum is very strong. The first Islamic bank, founded in 1975, but the Islamic banking industry and the prosperity of the insurance industry is later until the mid-1990. Islamic banking and insurance in the world market share of less than one percent. But with the deepening and development of international finance, the Islamic finance, fast growing has now formed a lot of Islamic financial services and the most concentrated gulf. At present, the gulf more influential Islamic financial services include ABU Dhabi, Doha, Dubai, Jeddah and Riyadh, Kuwait. Except in the gulf region, other parts of the Islamic financial development speed is very fast, including London, Malaysia, Singapore and Kuala Lumpur in Zurich and Geneva, Switzerland and other countries and regions. At present, UK is becoming Islamic financial business, Japan has joined the Islamic financial services commission (IFSB) and prepares to issue Islamic bonds, and establishment of Islamic insurance, Hong Kong, China has been applied to be Islamic finance committee members (Ma 2014). Islamic Financial Services commission (Islamic Financial Services Board, IFSB) is one of the world's most influential Islamic Financial group, the group has eight 112 inter-governmental international organizations, financial institutions and professional companies, including 58 regulators and 158 member states and industry association and the stock exchange. Until the end of 2013, the global banking assets under management of Islamic finance is about $\$ 1.7$ trillion (Zhang 2012), estimates by 2020, total assets will reach global Islamic financial institutions 3. \$25 trillion.

\section{The Basis and Advantage of Islamic Financial Development in Northwest China}

The Cultural Advantage. Islam was introduced into China has 1300 years, China's 56 ethnic groups of the Hui, Uygur, Kazak, Kirgiz, Dongxiang, Sarah, Tajikistan, Uzbekistan. the traditional beliefs are Islam, they in aspects such as religion, culture, trade and countries along the "silk road economic belt" has a very profound historical origin, is to further strengthen communication with the cultural economy of countries along the bridge and the link. China's muslins live mainly in the northwest of Xinjiang, Ningxia, Gansu and Qinghai area.

According to data, the Chinese Muslim population has reached 20.321 million, accounting for 3\% of China's population with Xinjiang (10.706 million, 57.99\%), Ningxia (1.865 million, 33. 99\%), Qinghai (844000, 17.51\%), Gansu (1.669 million 6.64\%), Shaanxi (141000, 0.4\%). In northwest China is China's Muslim population concentrated area, these areas have a number of known Islamic values and scholars of economic thought, more a lot of Islam Muslim population, there are suitable for the development of Islamic finance fertile soil.

The Geographical Advantage. Economic belt in northwest China is located in the "silk road" of the construction of the golden section, the silk road economic belt" is based on the concept of the ancient "silk road" of the contemporary economic and trade cooperation, has important strategic significance (Hu 2014). Building economic belt "silk road" is the service national strategy, based on their own advantages, enhance the level of planning and the important measures to actively into the nation's overall economic and diplomatic. The northwest region as an important section of economic "silk road belt ".

In recent years, with the deepening of national western development strategy implementation, the northwest region in highway, railway, aviation, inland water transport, port, pipeline construction with further development, formed a relatively perfect modern three-dimensional traffic system, the connection area business flow, logistics, flow, cash flow, information flow distribution and channel function, transportation hub and the overall location advantage continuously emerging. The continuous improvement of the infrastructure and the strategy of "the silk road economic belt" makes the northwest region in the future will certainly become an important base for the development of Chinese west trade and carriage of goods by onshore terminals. Construction of "silk road economic belt" is the national strategy in northwest service, actively into the nation's overall economic and 
diplomatic on the comprehensive advantages and the important measures to enhance the level of planning (Wang 2014).

The Experience of Developing of Islamic Financial Business. Due to China's northwest region in the promotion of cultural identity, geographical location, trade the congenital advantage of Islamic finance in north-west China have a certain degree of development and accumulated certain experience. Different Muslim population in China is mainly the northwest region, Islamic finance in the local religious people already have a certain history and folk basis, such as in Linxia Hui autonomous prefecture, Gansu province, since the reform and opening-up, there have been extensive with characteristic of Islamic finance folk finance, origin of the earlier "west road" is in the northwest Hui has deep influence. In the field of formal financial, as early as in 1997 in Lanzhou, Gansu province bank established Muslim branches, mainly in the service of Muslim population, its founding up to now, for the northwest region of the national economic development and the Muslim characteristic brand building and made a great contribution to ascend. Ningxia Hui autonomous region has been successfully held the bilateral economic and trade BBS for many times, promote and deepen the China and the Arab and Muslim world trade and financial activities, Ningxia Islamic banking business in general bank window experimental mode has made quite a success, highlights the advantages of Islamic finance in the development of national economy, for the further development of Islamic finance in our country, especially, the northwest has provided the beneficial reference and Experience.

\section{The Market Basics for Developing the Islamic Finance in Northwest China}

The Halal Industry Begun to Take Shape in the North West. Halal industry is Halal food, Halal food and Muslim supplies industry system. In recent years, under national policy support, the northwest five provinces Halal industry present a rapid development momentum, kept more than 10\% of the country's average annual growth rate (Chan 2013). Ningxia Muslim supplies and Halal food has become a main industry of Ningxia, Ningxia during the period of "twelfth five-year" Halal industry growth rate reached 20\%. In 2014 in Qinghai province has more than 300 Halal products processing and production companies, about 5500 food and beverage services enterprises, there are more than 23000 merchants engaged in Halal food, supplies, Halal products of foreign trade and exports reached $\$ 700$ million, Halal industry output value of 3 billion Yuan.

The Northwest Region on Deepening of Trade. Economic and trade cooperation between China and Arab countries has a long history, in 2010 the establishment of the "bilateral trade and economic cooperation BBS" marks the china-Arab trade into a broader development platform. At present, the level of economic and trade between China and Arab countries continued to improve, because of the cultural identity, the northwest area of Muslim supplies, Halal food, Halal food exports increase quickly, agricultural technology, science and technology education, deepening of cooperation in the field of cultural exchange, a mechanism of sharing information and steadily push forward regional tourism. With ever increasing bilateral exchanges and strengthen, Arab countries as the northwest region export increase significantly, the products are mainly concentrated in the Halal food and Muslim commodities, Halal food, medicine, feed additives, cashmere wool products, metal magnesium, activated carbon, silicon, etc., Saudi Arabia, Qatar, Bahrain, Kuwait, Oman, the united Arab emirates six gulf as main trading partners. In 2013, Linxia held a three-day China farm green agricultural products trade fair, a delegation to visit LinXia exhibition and Malaysia, Iran, Sudan, Egypt, Yemen and China Taiwan and other countries and regions of merchants have Halal industry development of LinXia project showed a keen interest in it also marks the northwestern region of Halal industry successfully taken the first step to develop the Middle East and southeast Asia market. The deal will not only make LinXia introducing investment 1.12 billion Yuan, more important is to build the LinXia Muslim regions and enterprises to develop the Halal industry at home and abroad cooperation and exchange platform. 


\section{The Current Contexts of Islamic Finance in Northwest China}

In recent years, with the constant change of the world trade patterns, the world's financial development also gradually from west to east, the contact of the financial deepening in China and western countries at the same time, the Islamic finance business is also increasing. The Citric Group in China and Bahrain Shamil bank was established in 2006 is mainly used for the investment real estate projects $\$ 100$ million Islamic fund, at the same time, the Dubai to mark on the development of Tanggu district of Tianjin Binhai project investment of about $\$ 2.73$ billion, these projects are flashes in the form of Islamic finance. Malaysia Hong Leong bank (Hong Kong) in 2007, approved by the Hong Kong monetary authority, can open a Islamic banking business in Hong Kong market window. In Yinchuan of Ningxia bank as the center, for the first time in 2009 formally opened Islamic banking, opened up a new stage of China's development of Islamic finance. Ningxia bank established Islamic financial advisory board and the Islamic finance department, mainly responsible for the Islamic finance management and supervision of audit Islamic finance division products conform to Islam. As the northwest Islamic nation based on common faith and win-win cooperation to the west open with China's opening and acceptance for Islamic finance to expand open to the west of northwest China laid a solid foundation.

To sum up, the Islam culture in northwest China has a deep and large Muslim population, along with the constant development of the economy in recent years, Muslim, Halal products export increase, and the northwest region of the existing experience, for the development of Islamic finance in the "area" under the background of national strategy, China's northwestern region has preliminary mature development of Islamic finance conditions.

\section{The Islamic Finance and Ethnic Characteristic Industry in Northwest Regions China}

The Development of Ethnic Characteristic Industry. The development of national characteristic industry is the life of a specific process, affects the certain areas of the national economy and social development. Characteristic industry as an effective way to improve the level of economic development in national regions, has been focus in economic development in national regions (Yang and Qin, 1999). The development of national characteristic industry by economic development level, the national development strategy, the influence of many factors such as regional economic relations. The northwest region is China's largest ethnic minority concentrated area. Natural condition, cultural customs, economic and social development in northwest China's ethnic minority areas, which is relatively backward and low level of development. Muslim Halal food supplies act the role tasted and characteristic cultural products. It has been formed with large international influence of the brand and national characteristic industrial clusters. With the implementation of the western development strategy, continuous development of national economy in northwest China, national and local characteristics constantly highlighted, ecological improvement of regional history in national again, and all kinds of characteristic industry booming, industry level, gradually strengthen the international competitiveness. National strategy is put forward and implemented to the northwest region providing a rare historical opportunity, also for ecological improvement ethnic economic zone and the development of characteristic industry provides the effective system and policy guarantee, the northwest region in the strategic position in national economy as a whole will be continuously emerging, the development of national characteristic industry will play an important role in the regional development, and will promote China's economy and the rest of the world's economic community contact and docking. In the face of the prospective development trend, Islamic trade and Islamic finance will become the engine to promote the development of northwest national characteristic industry.

China and the World Economic Community. With the development of economic globalization process, geo-economic cooperation continued to deepen regional trade groups and the economic community has become an inevitable trend of international finance and trade. Under the new international economic order, involving in the economic community of nations will be isolated and 
out of the world economy, this will affect the economic development of a country and region and its international influence and voice. It is under this kind of new international trends, China proposed the development strategy to promote China and the rest of the world's economic community, to build effective regional cooperation platform. Through the "silk road" of the Chinese history to expand cooperation in the field of economy, politics, culture is the trend of world economic changes and the historical trend is the inevitable development direction, fully embodies the international perspective of the development of China. Cultural distance is the important factors that impact the world trade; the culture of the shorter distance is one of the main reasons for the world economic community formation. Culture and system as the most important characteristics of state and society the whole country. Value orientation and behavior have a decisive influence to have a great impact on the economic and trade. The studies have shown that national culture and distance can explain $16 \%$ of China's export trade.

\section{Conclusions}

In northwest China and countries along the "silk road" have a very profound ethnic origin, history, culture and economy, and economic belt "silk road" important strategic channel, developing Islamic finance to promote the pace of the northwestern region open to the west, speed up the implementation of the strategy of "area" play an important role. But because of Islamic finance in our country has just started in law and system. Operation and management is still relatively weak, so the northwest region in the development of Islamic finance should adopt the method of setting up and improving the national Islamic finance related system, strengthening financial opening in northwest region, strengthening the talents training of Islamic financial, Raising up Islamic finance management.

\section{Acknowledgements}

This work was supported by University Planning Funds for "New Silk Road Economic Belt" by Northwest University for Nationalities (Grant XSCZL201602) and by National Social Science Foundation of China (Grant No.12BJL072).

\section{References}

[1] Jiang Yingmei, Islamic finance globalization and its development prospect in China. Journal of West Africa. 2(2014)87-97

[2] Zhao Zhonglong, Islamic finance, law and economics analysis. Journal of academic exchanges. 8(2014)112-121

[3] Lulu Feng, Rethinking on Islamic economic modernization problem. Journal of Ningxia Social Sciences. 6(2011)6-15.

[4] Zhang Ruiliang, Reference and development of Islamic finance in China. Journal of research in the Arab world. 1(2012)16-26.

[5] Hu Angang, "the silk road economic belt": connotation, strategic positioning and implementation path. Journal of Xinjiang Normal University. 2(2014)89-98.

[6] Wang Yongzhen, Silk Road economic belt in Gansu province and Lanzhou economic zone industrial linkage development research. Productivity Research. 2014, (12).

[7] [Tian Hui Jiang, National cultural distance influence on China's foreign trade, based on the gravity model of trade data of 31 countries and regions analysis. Journal of international trade issues. 2012, (3). 